\title{
Aqueous-phase ozonolysis of methacrolein and methyl vinyl ketone: a potentially important source of atmospheric aqueous oxidants
}

\author{
Z. M. Chen, H. L. Wang, L. H. Zhu, C. X. Wang, C. Y. Jie, and W. Hua \\ State Key Laboratory of Environmental Simulation and Pollution Control, College of Environmental Sciences and \\ Engineering, Peking University, Beijing 100871, China
}

Received: 19 October 2007 - Published in Atmos. Chem. Phys. Discuss.: 5 December 2007

Revised: 3 April 2008 - Accepted: 12 April 2008 - Published: 24 April 2008

Abstract. Recent studies indicate that isoprene and its gasphase oxidation products could contribute a considerable amount of aerosol through aqueous-phase acid-catalyzed oxidation with hydrogen peroxide $\left(\mathrm{H}_{2} \mathrm{O}_{2}\right)$, although the source of $\mathrm{H}_{2} \mathrm{O}_{2}$ is unclear. The present study revealed a potentially important route to the formation of aqueous oxidants, including $\mathrm{H}_{2} \mathrm{O}_{2}$, from the aqueous-phase ozonolysis of methacrolein (MAC) and methyl vinyl ketone (MVK). Laboratory simulation was used to perform the atmospheric aqueous-phase ozonolysis at different $\mathrm{pHs}$ and temperatures. Unexpectedly high molar yields of the products, including hydroxylmethyl hydroperoxide (HMHP), formaldehyde ( $\mathrm{HCHO})$ and methylglyoxal (MG), of both of these reaction systems have been seen. Moreover, these yields are almost independent of $\mathrm{pH}$ and temperature and are as follows: (i) for $\mathrm{MAC}-\mathrm{O}_{3}, 70.3 \pm 6.3 \% \mathrm{HMHP}, 32.3 \pm 5.8 \% \mathrm{HCHO}$ and $98.6 \pm 5.4 \% \mathrm{MG}$; and (ii) for $\mathrm{MVK}-\mathrm{O}_{3}, 68.9 \pm 9.7 \%$ HMHP, $13.3 \pm 5.8 \% \mathrm{HCHO}$ and $75.4 \pm 7.9 \%$ MG. A yield of $24.2 \pm 3.6 \%$ pyruvic acid has been detected for MVK$\mathrm{O}_{3}$. HMHP is unstable in the aqueous phase and can transform into $\mathrm{H}_{2} \mathrm{O}_{2}$ and $\mathrm{HCHO}$ with a yield of $100 \%$. We suggest that the aqueous-phase ozonolysis of MAC and MVK can contribute a considerable amount of oxidants in a direct and indirect mode to the aqueous phase and that these compounds might be the main source of aqueous-phase oxidants. The formation of oxidants in the aqueous-phase ozonolysis of MAC and MVK can lead to substantial aerosol formation from the aqueous-phase acid-catalyzed reaction of $\mathrm{H}_{2} \mathrm{O}_{2}$ with MAC, even if there are no other sources of oxidants.

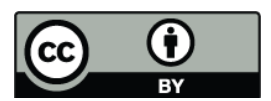

Correspondence to: Z. M. Chen (zmchen@pku.edu.cn)

\section{Introduction}

An increasing amount of attention has been paid to organic aerosols because of their significant climate effect and because they have an important role in key atmospheric processes (Gelencsér and Varga, 2005) (e.g. acting as cloud condensation nuclei, Navakov and Penner, 1993, and scattering and absorbing solar radiation, Andreae and Crutzen, 1997). Photooxidation products of monoterpenes, which are important biogenic volatile organic compounds (VOCs) emitted mainly by terrestrial vegetation, contribute to the secondary organic aerosol (SOA) budget (Kavouras et al., 1998; Kavouras and Stephanou, 2002). Recently, the potentially increasing importance of isoprene regarding SOAs has been realized (Wiedinmyer et al., 2006). It has been estimated that a global isoprene emission flux of 500-750 $\mathrm{Tg} \mathrm{yr}^{-1}$ (Guenther et al., 2006), which accounts for $\sim 50 \%$ of global VOCs. Contrary to previous assumptions, Claeys et al. (2004a) reported, for the first time, isoprene and its gas-phase oxidation products could contribute to the formation of SOA with an amount of $2 \mathrm{Tg} \mathrm{yr}^{-1}$. Subsequent studies of additional SOA production pathways confirmed this conclusion and increased this estimation. Henze et al. (2006) estimated that the amount of SOA produced directly from isoprene is $6.2 \mathrm{Tg} \mathrm{yr}^{-1}$, only considering the contribution from $\mathrm{OH}$ oxidation. Hoyle et al. (2007) estimated that the amount of SOA from the oxidation products of isoprene is $15 \mathrm{Tg} \mathrm{yr}^{-1}$. Matsunaga et al. (2005) estimated a source of SOA from isoprene in the range of $10-120 \mathrm{Tg} \mathrm{yr}^{-1}$. Obviously, the amount of isoprene SOA may be larger as more and more laboratory and field evidences are found. This is a substantial contribution to the global biogenic SOA budget $\left(8-40 \mathrm{Tg} \mathrm{yr}^{-1}\right)$ (Penner et al., 2001).

The estimations about the amount of isoprene SOA include the amount from both the gas-phase reaction and

Published by Copernicus Publications on behalf of the European Geosciences Union. 
aqueous-phase reaction. Recently, several laboratory studies have revealed that SOA can be formed from isoprene and its gas-phase oxidation products through the acid-catalyzed aqueous-phase reaction in solution (Claeys et al., 2004b; Gelencsér and Varga, 2005; Quivet et al., 2007; Ervens et al., 2008), the reaction in the presence of droplets with a yield of SOA from isoprene about $0.22 \%$ (Böge et al., 2006), the process of cloud processing with an amount about $1.6 \mathrm{Tg} \mathrm{yr}^{-1}$ (Lim et al., 2005) and the reaction on acidic humid particles (Surratt et al., 2006; Tsigaridis and Kanakidou, 2007). In the studies conducted so far, however, an important question has not been addressed: what is the source of aqueous oxidants that cause the formation of SOA from isoprene and its gasphase oxidation products? Therefore, we suggest that much better insights into the source of aqueous oxidants are vital for a better understanding of the mechanisms by which isoprene and its gas-phase oxidation products yield SOA.

It has been assumed that the major aqueous-phase oxidants - namely, hydrogen peroxide $\left(\mathrm{H}_{2} \mathrm{O}_{2}\right)$ and $\mathrm{HO}_{\mathrm{x}}(\mathrm{OH}$ and $\mathrm{HO}_{2}$ ) radicals - come mainly from the gas phase. However, with increased knowledge of aqueous-phase reactions, it has been found that many such reactions can also produce oxidants and, sometimes, aqueous-phase oxidants are produced mainly from aqueous-phase reactions (Anastasio et al., 1994; Finlayson-Pitts and Pitts, 2000; Valverde-Canossa et al., 2005). Smog chamber experiments have revealed that humid conditions are more favorable for the production of peroxides than are the dry conditions in the gas-phase ozonolysis of alkenes (Gäb et al., 1995; Neeb et al., 1997; Sauer et al., 1999). Accordingly, the aqueous-phase ozonolysis of alkenes might also produce a considerable yield of peroxides because of the abundance of water molecules (Gäb et al., 1995). Taking into account the huge emissions of biogenic alkenes, it is logical to presume that the aqueousphase ozonolysis of alkenes might contribute a considerable amount of oxidants to the aqueous phase, even if only a small number of alkenes participate in aqueous-phase reactions.

Methacrolein (MAC) and methyl vinyl ketone (MVK), as the major constituents of first-generation carbonyl products in the oxidation of isoprene, account for a combined molar yield of $>50 \%$ in the conversion of isoprene (Montzka et al., 1993; Li et al., 1997; Griffin et al., 1999; Simpson et al., 1999; Atkinson and Arey, 2003). Besides the secondary source from the oxidation of isoprene, MAC and MVK might also be directly emitted by anthropogenic sources (Biesenthal and Shepson, 1997). Hence, it can be estimated that there is $>320 \mathrm{Tg} \mathrm{yr}^{-1}$ of MAC and MVK present in the atmosphere. Moreover, the tropospheric lifetimes of MAC and MVK are estimated to be 6-10 h (Gierczak et al., 1997). Therefore, it can be presumed that MAC and MVK participate in and profoundly impact atmospheric chemistry with their huge quantities and high reactivity. However, the significance of their aqueous-phase reactions in the atmosphere requires evaluation.
Iraci et al. (1999) estimated that only $0.02 \%$ of the total amount of MAC and $0.1 \%$ of the total amount of MVK enter the aqueous phase under a condition of gas-aqueous partition equilibrium at $298 \mathrm{~K}$, based on the Henry constants of the compounds (i.e. $6.5 \mathrm{M} \mathrm{atm}^{-1}$ for MAC and $41 \mathrm{M} \mathrm{atm}^{-1}$ for MVK, Allen et al., 1998; Iraci et al., 1999), choosing $1 \times 10^{-6} \mathrm{~cm}^{-3} \mathrm{H}_{2} \mathrm{O} / \mathrm{cm}^{3}$ air $\left(1 \mathrm{~g} \mathrm{H}_{2} \mathrm{O} / \mathrm{cm}^{3}\right)$ as a generous estimate of cloud liquid water content (Pruppacher and Klett, 1997). According to this arithmetic, it can be estimated that only $0.00004 \%$ of the total isoprene present will reside in the aqueous phase at $298 \mathrm{~K}$, based on its Henry constant of $1.3 \times 10^{-2} \mathrm{M} \mathrm{atm}^{-1}$ at this temperature (Allen et al., 1998). If this ratio were combined with the global isoprene emission flux of $625 \mathrm{Tg} \mathrm{yr}^{-1}$ (Guenther et al., 2006), the amount of SOA derived from the aqueous-phase reaction of isoprene would be only $0.00025 \mathrm{Tg} \mathrm{yr}^{-1}$, even though isoprene molecules partitioning in the aqueous phase are completely transformed into SOA. Among the gas-phase oxidation products of isoprene, MAC, which is estimated as $160 \mathrm{Tg} \mathrm{yr}^{-1}$ in the atmosphere, is an important contributor to SOA (Claeys, et al., 2004b; Surratt et al., 2006). However, even though the total amount of MAC partitioning in the aqueous phase $(0.02 \%$, Iraci et al., 1999) were completely transformed into SOA, its burden to SOA could be estimated to be $0.032 \mathrm{Tg} \mathrm{yr}^{-1}$. This value is much lower than the amount of isoprene SOA from aqueous-phase reaction estimated from the field measurements and laboratory studies mentioned earlier. This indicates that the Henry constant might not be the crucial factor in determining the amount of a compound that participates in aqueous-phase reactions in the atmosphere. The reasons for higher partitioning into the particle phase may be: (i) the Henry constant could be enhanced significantly by ionic strength effects; (ii) the reactant partitions into non-aqueous moieties of the particles; (iii) in presence of a reaction, the reaction removes the reactant driving more of it from the gas phase into the liquid. Consequently, in the atmosphere, the amount of a compound that participates in the aqueous-phase reaction should be much larger than the equilibrium amount calculated from the simple gasaqueous equilibrium determined by its Henry constant. Similarly, it can be estimated that a huge amount of MAC and MVK participates in the aqueous-phase reaction. Therefore, it is extremely important to study aqueous-phase reactions of MAC and MVK.

In the present study, an experimental investigation of the ozonolysis of MAC and MVK in the aqueous phase was carried out to determine the source of oxidants in the aqueousphase reaction of isoprene and other alkenes. The major products, including second-generation carbonyls, peroxides and organic acids, were identified and quantified, and their yields were determined. In addition, reaction mechanisms were proposed on the basis of experimental results. Finally, the atmospheric implications regarding the source of oxidants in the atmospheric aqueous phase are discussed. 


\section{Experimental}

The solutions were prepared using MVK (Avocado, 95+\%) and MAC (Sigma, 95+\%) diluted in ultrapure water (Mili-Q). The concentrations of MAC and MVK used were $2-5 \mu \mathrm{M}$. As blank experiments, the mixtures of water with MAC or MVK were tested before the final series of aqueous-phase reactions were carried out, and no peroxides, other carbonyl compounds or organic acids were detected. These reactant solutions were adjusted to different $\mathrm{pHs}$ in $\mathrm{pH}$-conditional experiments.

The experimental apparatus comprised an ozone generator, an ozone solution generator and an aqueous reactor, each of which was made of quartz glass. Ozone solution was prepared by bubbling ozone through a 2.6-1 water solution at a flow rate of $60 \mathrm{ml} / \mathrm{min} . \mathrm{O}_{3}$ was generated by $\mathrm{UV}$ irradiation of $\mathrm{O}_{2}$, and the concentration of gas-phase $\mathrm{O}_{3}$ was $\sim 280 \mathrm{ppm}$ at $298 \mathrm{~K}$. The concentration of the $\mathrm{O}_{3}$ solution did not increase after $120 \mathrm{~min}$, and was in the order of several micromolar.

The aqueous-phase experiments were performed by mixing $450 \mathrm{ml}$ of $\mathrm{O}_{3}$ solution with $50 \mathrm{ml}$ of organic reactant solution in the aqueous reactor. The reaction solution was shaken thoroughly and placed in a thermostat in darkness. A $15-\mathrm{ml}$ gas space was left over the liquid level so that the reaction solution could be mixed. Because of the existence of the top gas space, the upper limits for the loss of aqueous ozone, MAC and MVK were estimated to be $\sim 7.1 \%, 0.02 \%$ and $0.006 \%$, respectively, at $298 \mathrm{~K}$, based on their Henry constants. Therefore, the contribution of the gas-phase reaction was mostly eliminated and, thus, the reaction could be regarded as an aqueous-phase reaction. Additionally, a small amount of $\mathrm{H}_{2} \mathrm{O}_{2}\left(<10 \%\right.$ of the $\mathrm{H}_{2} \mathrm{O}_{2}$ produced from the reactions) was found in the ozone solution before the organic reactant was added. Several possible mechanisms exist for aqueous $\mathrm{H}_{2} \mathrm{O}_{2}$ formation from $\mathrm{O}_{3}$ and involve species such as $\mathrm{HO}, \mathrm{HO}_{2}$ and $\mathrm{O}_{2}^{-}$acting as intermediates (Heikes et al., 1982; Chameides and Davies, 1984). The $\mathrm{H}_{2} \mathrm{O}_{2}$ formed in the $\mathrm{O}_{3}$ solution was measured in each experiment and was considered in the data analysis.

Both the reactants and the major products were determined in the experiments. Carbonyl compounds were analyzed by determining their derivatives of 2,4-dinitrophenyhydrazine (DNPH) with high-performance liquid chromatography (HPLC) (Agilent 1100, USA). Peroxides were analyzed online using post-column derivatization method by HPLC, in which hydroxyphenylacetic acid was oxidized to a fluorescent dimer by peroxides and catalyzed by hemin; this method was described in detail in our previous work (Xu and Chen, 2005). Organic acids were analyzed using ion chromatography with an $\mathrm{ED}_{50}$ conductivity detector (DIONEX 2650, USA). The concentration of ozone in the aqueous phase was determined by indigo disulphonate spectrophotometry.

\section{Results and discussion}

The ozonolysis of MAC and MVK in the aqueous phase was studied at different $\mathrm{pHs}(\mathrm{pH}=7.0,5.4$ and 3.0) and temperatures $\left(t=4^{\circ} \mathrm{C}, 10^{\circ} \mathrm{C}, 25^{\circ} \mathrm{C}\right.$ and $\left.40^{\circ} \mathrm{C}\right)$. In the MAC$\mathrm{O}_{3}$ system, four products were identified: formaldehyde (HCHO), methylglyoxal (MG), hydroxylmethyl hydroperoxide (HMHP) and $\mathrm{H}_{2} \mathrm{O}_{2}$. In addition to these products, pyruvic acid (PYA) was detected in the $\mathrm{MVK}-\mathrm{O}_{3}$ system. The molar yields of these products were determined relative to the conversion of MAC or MVK.

A typical pattern of kinetics curves for the ozonolysis of MAC is shown in Fig. 1a. It can be seen that the ozonolysis time was $<5 \mathrm{~min}$. The concentration of MAC decreased quickly within $5 \mathrm{~min}$ and then remained constant, indicating that ozone was completely consumed within this time, which was confirmed by ozone analysis. The concentration of MG was unchanged after $5 \mathrm{~min}$, but the phenomena were different for $\mathrm{HCHO}, \mathrm{H}_{2} \mathrm{O}_{2}$ and $\mathrm{HMHP}$. The concentration of HMHP decreased with reaction time; the opposite was true for $\mathrm{HCHO}$ and $\mathrm{H}_{2} \mathrm{O}_{2}$. The results were similar for the MVK$\mathrm{O}_{3}$ aqueous-phase reaction (Fig. 1b).

According to the results described, we speculate that $\mathrm{HMHP}$ decomposes in the aqueous solution, yielding $\mathrm{HCHO}$ and $\mathrm{H}_{2} \mathrm{O}_{2}$. The yields of $\mathrm{HCHO}$ and $\mathrm{H}_{2} \mathrm{O}_{2}$ from the decomposition can be derived from the linear regression in Fig. 2, and the values of $\Delta \mathrm{HCHO} / \Delta \mathrm{HMHP}$ and $\Delta \mathrm{H}_{2} \mathrm{O}_{2} / \Delta \mathrm{HMHP}$ are 0.95 and 1.13 , respectively. These values indicate that HMHP formed in the aqueous-phase ozonolysis of MAC and MVK decomposes at a rapid rate exclusively into $\mathrm{HCHO}$ and $\mathrm{H}_{2} \mathrm{O}_{2}$. The half-life of HMHP in the solution, $\tau_{\mathrm{HMHP}, 1 / 2}$, was calculated. At neutral $\mathrm{pH}, \tau_{\mathrm{HMHP}, 1 / 2}$ is in the order of several tens of minutes but, under slightly acidic conditions (i.e. $\mathrm{pH} \leq 5.4$ ), $\tau_{\mathrm{HMHP}, 1 / 2}$ is at least $100 \mathrm{~min}$. Hence, the $\mathrm{HCHO}$ and $\mathrm{H}_{2} \mathrm{O}_{2}$ observed were produced not only by direct generation but also by decomposition of HMHP. The real primary yields of $\mathrm{HCHO}$ and $\mathrm{H}_{2} \mathrm{O}_{2}$ in the reaction systems were obtained based on further experimental results.

As illustrated in Fig. 3, HMHP was stable and its yield was unchanged during the experimental period under the conditions $t=4^{\circ} \mathrm{C}, \mathrm{pH}=3$.0. Correspondingly, the yields of $\mathrm{HCHO}$ and $\mathrm{H}_{2} \mathrm{O}_{2}$ did not increase against the reaction time. Under these conditions, $\mathrm{H}_{2} \mathrm{O}_{2}$ had a negligible yield $(0.29 \pm 2.0 \%)$, indicating that the ozonolysis reaction cannot produce $\mathrm{H}_{2} \mathrm{O}_{2}$ directly. Thus, $\mathrm{H}_{2} \mathrm{O}_{2}$ detected in the reaction was derived from the decomposition of HMHP. However, the case is different for $\mathrm{HCHO}$, which has two sources - direct formation and decomposition of HMHP - even under the conditions $t=4^{\circ} \mathrm{C}, \mathrm{pH}=3.0$. The experimental results indicate that HMHP was decomposed partially during the 24-h period for the derivatization of HCHO-DNPH, although no distinct decrease in HMHP was observed during the 95min ozonolysis reaction period (Fig. 3). However, during the derivatization period, the proportions of the decomposition of HMHP in different samples collected at the different 

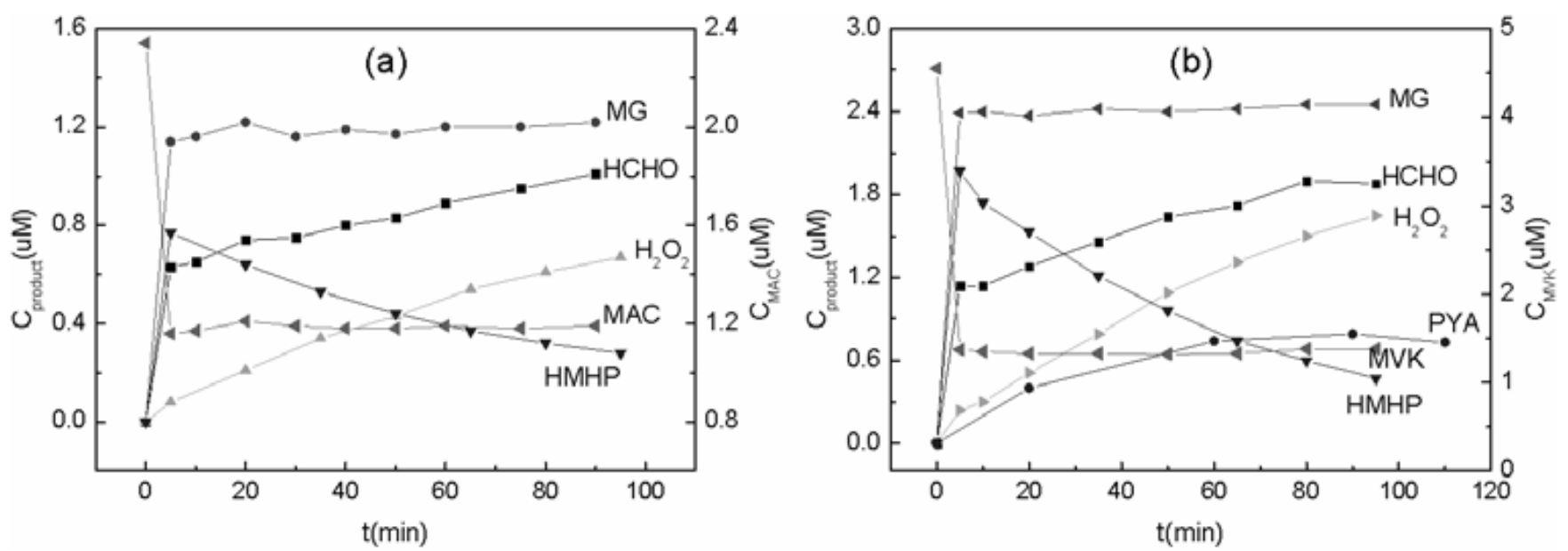

Fig. 1. Temporal concentration profiles of reactant and products in the aqueous-phase ozonolysis of (a) $\mathrm{MAC}$ and (b) $\mathrm{MVK}\left(25^{\circ} \mathrm{C}, \mathrm{pH}=7.0\right)$.

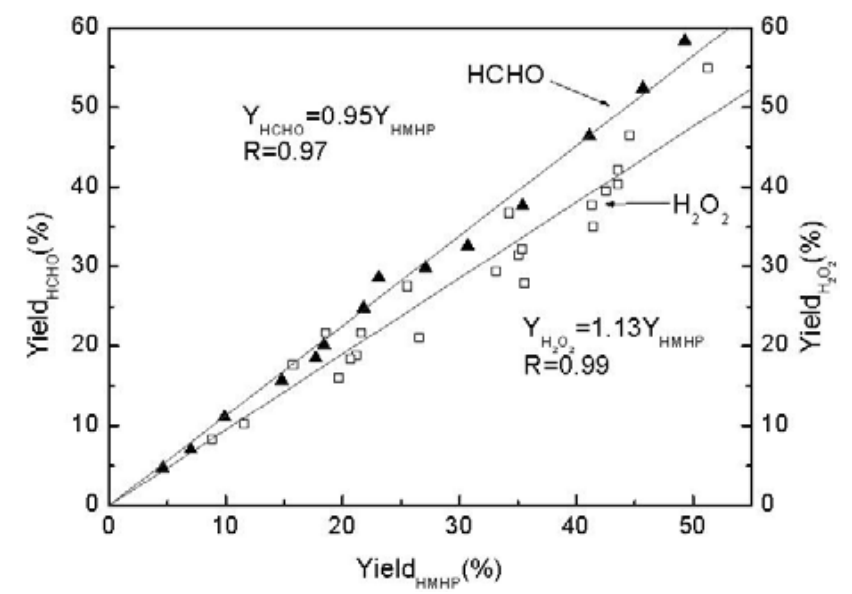

Fig. 2. Regression of the transformation ratios of $\Delta \mathrm{HCHO} / \Delta \mathrm{HMHP}$ and $\Delta \mathrm{H}_{2} \mathrm{O}_{2} / \Delta \mathrm{HMHP}$.

ozonolysis reaction times should be the same because of the same derivatization conditions $(\mathrm{pH}=2.0)$ of $\mathrm{HCHO}$. Therefore, the calculated yields of $\mathrm{HCHO}$ are the same in the samples (Fig. 3). Consequently, the yield of HCHO obtained under the conditions $t=4^{\circ} \mathrm{C}, \mathrm{pH}=3.0$ is still not its real primary yield in the aqueous-phase ozonolysis of MAC because of the limitation of the offline analytical method used for $\mathrm{HCHO}$. The yield of HCHO obtained under these conditions should actually be higher than the real primary yield. According to the analysis described, the real primary yield of $\mathrm{HCHO}$ should be equal to the difference between the yield of $\mathrm{HCHO}$ when HMHP has decomposed totally and the real primary yield of HMHP. This is similar to the values of the $\mathrm{MVK}-\mathrm{O}_{3}$ system.

The experimental results under different conditions are summarized in Table 1. The yields of peroxides and secondgeneration carbonyls are almost independent of $\mathrm{pH}$ and tem-

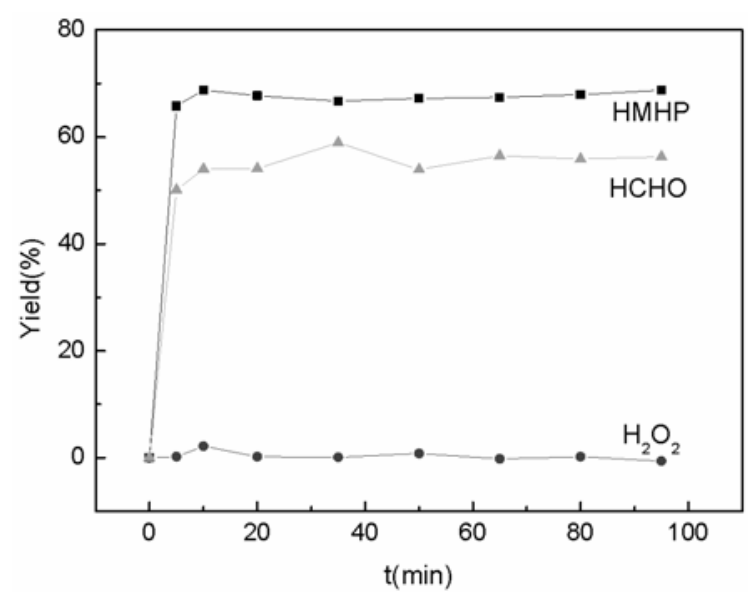

Fig. 3. Temporal yield profiles of $\mathrm{HMHP}, \mathrm{HCHO}$ and $\mathrm{H}_{2} \mathrm{O}_{2}$ in MAC $-\mathrm{O}_{3}$ aqueous-phase reactions under the conditions $t=4^{\circ} \mathrm{C}$, $\mathrm{pH}=3.0$.

perature in the aqueous ozonolysis of MAC and MVK. The organic acids were also determined at $\mathrm{pH}=7.0$ and $t=25^{\circ} \mathrm{C}$. PYA was detected as the only organic acid in the ozonolysis of MVK in the aqueous phase, with a yield of $24.2 \pm 3.6 \%$, and no organic acids were detected in the ozonolysis of MAC in the aqueous phase. Both of these reaction systems have a fine carbon balance approaching 100\%: $99.6 \pm 6.3 \%$ for $\mathrm{MAC}-\mathrm{O}_{3}$ and $95.4 \pm 9.7 \%$ for $\mathrm{MVK}-\mathrm{O}_{3}$.

Such high yields of peroxides and second-generation carbonyls are unexpected. In particular, the total yield of peroxides is $\sim 70 \%$ for both $\mathrm{MAC}-\mathrm{O}_{3}$ and $\mathrm{MVK}-\mathrm{O}_{3}$ aqueousphase reaction systems, and this value is much higher than those previously reported for the aqueous ozonolysis of alkenes. Gäb et al. (1995) determined the yields of alkyl and hydroxyalkyl hydroperoxides in the ozonolysis of ethene, isoprene and three other alkenes under two conditions: in 
Table 1. Yields (\%) of products in the aqueous ozonolysis of MAC and MVK under different conditions.

\begin{tabular}{|c|c|c|c|c|c|c|c|}
\hline \multirow[b]{2}{*}{$t\left({ }^{\circ} \mathrm{C}\right)$} & \multirow[b]{2}{*}{$\mathrm{pH}$} & \multicolumn{3}{|c|}{$\mathrm{MAC}-\mathrm{O}_{3}$} & \multicolumn{3}{|c|}{$\mathrm{MVK}-\mathrm{O}_{3}$} \\
\hline & & $\mathrm{HCHO}^{\mathrm{a}}$ & $\mathrm{MG}$ & HMHP & $\mathrm{HCHO}^{\mathrm{a}}$ & MG & НMHP \\
\hline & 3.0 & $34.9 \pm 3.0$ & $96.1 \pm 2.4$ & $67.6 \pm 3.2$ & $14.4 \pm 1.2$ & $73.7 \pm 1.1$ & $67.8 \pm 2.2$ \\
\hline \multirow[t]{3}{*}{4} & 5.4 & $32.6 \pm 2.6$ & $97.2 \pm 3.0$ & $69.9 \pm 2.0$ & $13.1 \pm 1.9$ & $76.1 \pm 1.9$ & $69.1 \pm 2.8$ \\
\hline & 7.0 & $33.8 \pm 2.5$ & $97.4 \pm 2.6$ & $68.7 \pm 5.5$ & $10.0 \pm 2.9$ & $74.9 \pm 1.8$ & $72.2 \pm 3.2$ \\
\hline & 3.0 & $33.2 \pm 5.5$ & $99.1 \pm 2.0$ & $69.3 \pm 2.9$ & $12.9 \pm 2.1$ & $74.2 \pm 1.0$ & $69.3 \pm 3.0$ \\
\hline \multirow[t]{3}{*}{10} & 5.4 & $30.0 \pm 1.9$ & $97.4 \pm 3.2$ & $72.5 \pm 5.4$ & $14.7 \pm 5.1$ & $76.2 \pm 1.0$ & $67.5 \pm 2.7$ \\
\hline & 7.0 & $30.1 \pm 2.3$ & $96.5 \pm 2.8$ & $72.4 \pm 6.3$ & $12.2 \pm 2.3$ & $75.7 \pm 0.8$ & $70.0 \pm 2.8$ \\
\hline & 3.0 & $31.9 \pm 3.6$ & $98.6 \pm 5.4$ & $70.6 \pm 4.5$ & $18.3 \pm 1.7$ & $74.3 \pm 2.7$ & $63.9 \pm 4.8$ \\
\hline \multirow[t]{3}{*}{25} & 5.4 & $31.4 \pm 4.7$ & $98.9 \pm 4.8$ & $71.1 \pm 3.2$ & $15.5 \pm 3.0$ & $74.2 \pm 2.1$ & $66.7 \pm 4.1$ \\
\hline & 7.0 & $30.6 \pm 3.7$ & $102.2 \pm 5.4$ & $71.9 \pm 3.7$ & $13.4 \pm 4.9$ & $75.4 \pm 1.7$ & $68.8 \pm 2.4$ \\
\hline & 3.0 & $30.9 \pm 5.0$ & $100.2 \pm 5.0$ & $71.6 \pm 5.0$ & $11.6 \pm 4.8$ & $74.6 \pm 8.5$ & $70.6 \pm 9.5$ \\
\hline \multirow[t]{2}{*}{40} & 5.4 & $34.1 \pm 5.8$ & $99.5 \pm 4.5$ & $68.4 \pm 6.2$ & $12.3 \pm 5.8$ & $77.4 \pm 7.1$ & $69.9 \pm 9.7$ \\
\hline & 7.0 & $32.7 \pm 3.6$ & $100.0 \pm 3.5$ & $69.8 \pm 4.2$ & $11.5 \pm 4.7$ & $78.2 \pm 7.9$ & $70.7 \pm 7.0$ \\
\hline \multirow{2}{*}{\multicolumn{2}{|c|}{$\begin{array}{c}\text { Mean } \\
\text { Total C }\end{array}$}} & $32.3 \pm 5.8$ & $98.6 \pm 5.4$ & $70.3 \pm 6.3$ & $13.3 \pm 5.8$ & $75.4 \pm 7.9$ & $68.9 \pm 9.7$ \\
\hline & & & $99.6 \pm 6.3$ & & & $95.4 \pm 9.7^{\mathrm{c}}$ & \\
\hline
\end{tabular}

a The real primary yield of HCHO was calculated by subtracting the yield of HMHP from the yield of HCHO when HMHP had decomposed totally.

b Total C $=\left(\right.$ Yield $_{\mathrm{HCHO}}+$ Yield $_{\mathrm{HMHP}}+$ Yield $_{\mathrm{MG}} \times 3+$ Yield $\left._{\mathrm{PYA}} \times 3\right) / 4$.

${ }^{c}$ The yield of PYA $(24.2 \pm 3.6 \%)$ has been added to the measurement of carbon balance of the $\mathrm{MVK}-\mathrm{O}_{3}$ aqueous reaction system.

dry air and in water. The ozonolysis in water produced almost exclusively 1-hydroxyalkyl hydroperoxides, in 10-30\% yields, whereas the dry gas-phase ozonolysis produced few peroxides $(<1 \%)$, unless there were methyl substituents in the double bonds, in which case a yield of up to $5 \%$ of methyl hydroperoxide was produced. It is difficult to compare the results of the present study with those of Gäb et al. (1995) because the reaction conditions were different. Gäb et al. (1995) carried out their reactions at concentrations $\sim 20-40$ times those in the present study. Moreover, the MAC and MVK we studied were different from the alkenes that they studied. However, the yields of peroxides in aqueous-phase reactions were much higher than those in the gas-phase reaction for both their study and the present study. Therefore, we conclude that water molecules can significantly contribute to the increased yield of peroxides in the ozonolysis of $\mathrm{C}=\mathrm{C}$-containing compounds via the pathway of generating 1-hydroxyalkyl hydroperoxides (namely, HMHP) for vinyl compounds.

The stoichiometric proportions of the ozonolysis of MAC and MVK in the aqueous phase were obtained using a linear regression method based on the experimental results, with strong linear relationships (i.e. $\mathrm{R}_{\mathrm{MAC} / \mathrm{O} 3}=0.98(n=21)$ and $\left.R_{\mathrm{MVK} / \mathrm{O} 3}=0.99(n=24)\right)$ (Fig. 4). The proportions of $\Delta \mathrm{MAC} / \Delta \mathrm{O}_{3}$ and $\Delta \mathrm{MVK} / \Delta \mathrm{O}_{3}$ were obtained as 0.93 and 1.03 , respectively, which indicates that the aqueous ozonolysis of MAC and MVK proceeds at a stoichiometric proportion of 1:1.

We propose possible mechanisms for the ozonolysis of MAC and MVK in the aqueous phase based on the experimental results discussed (Fig. 5).

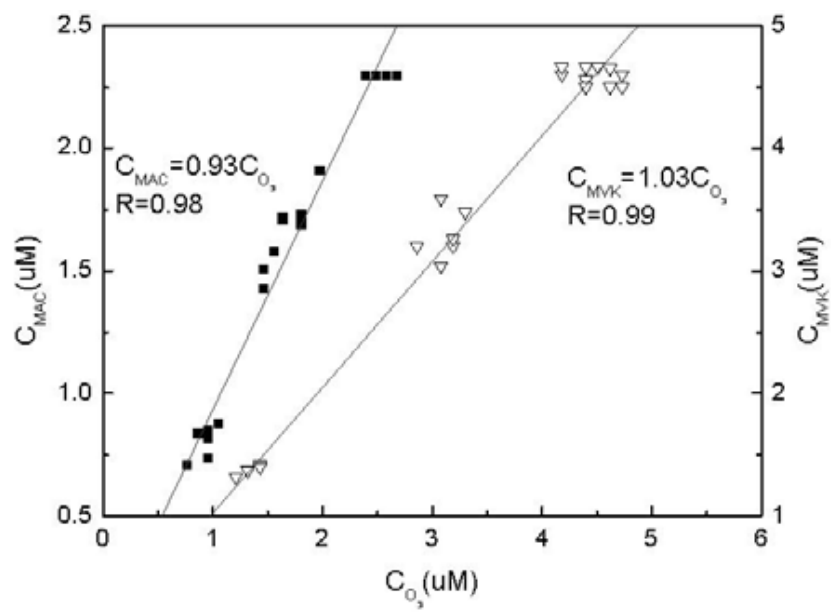

Fig. 4. The linear regression of the reactant ratios of $\mathrm{MAC} / \mathrm{O}_{3}$ and $\mathrm{MVK} / \mathrm{O}_{3}$.

The aqueous-phase reaction of ozone with alkenes is, through analogy with the gas phase, believed to proceed via the addition of ozone to the double bond to form a molozonide, which decomposes rapidly into a carbonyl compound and a corresponding Criegee radical (Hatakeyama and Akimoto, 1994). There are two possible pathways for the formation of molozonide following the addition of $\mathrm{O}_{3}$ to $\mathrm{MAC}$ or MVK, yielding $\left[\mathrm{CH}_{2} \mathrm{OO}\right]^{*}$ and $\left[\mathrm{CH}_{3} \mathrm{C}(\mathrm{OO}) \mathrm{CHO}\right]^{*}$ for MAC $-\mathrm{O}_{3}$, and $\left[\mathrm{CH}_{2} \mathrm{OO}\right]^{*}$ and $\left[\mathrm{CH}_{3} \mathrm{COCHOO}\right]^{*}$ for MVK$\mathrm{O}_{3}$. Then, $\left[\mathrm{CH}_{2} \mathrm{OO}\right]^{*}$ is collisionally stabilized and reacts with $\mathrm{H}_{2} \mathrm{O}$ to form HMHP (Gäb et al., 1985). HMHP is 


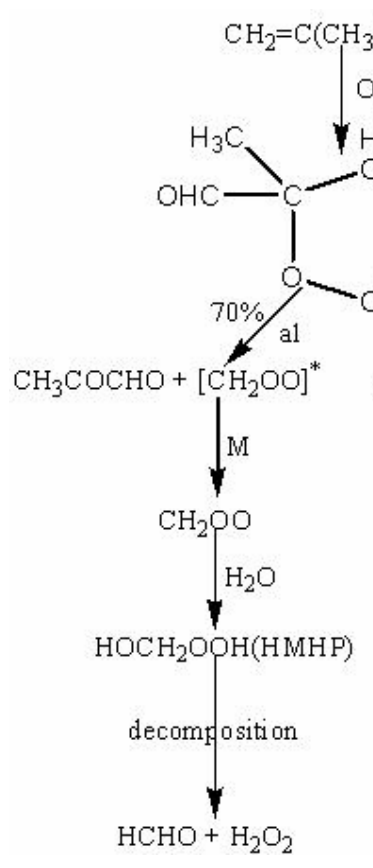

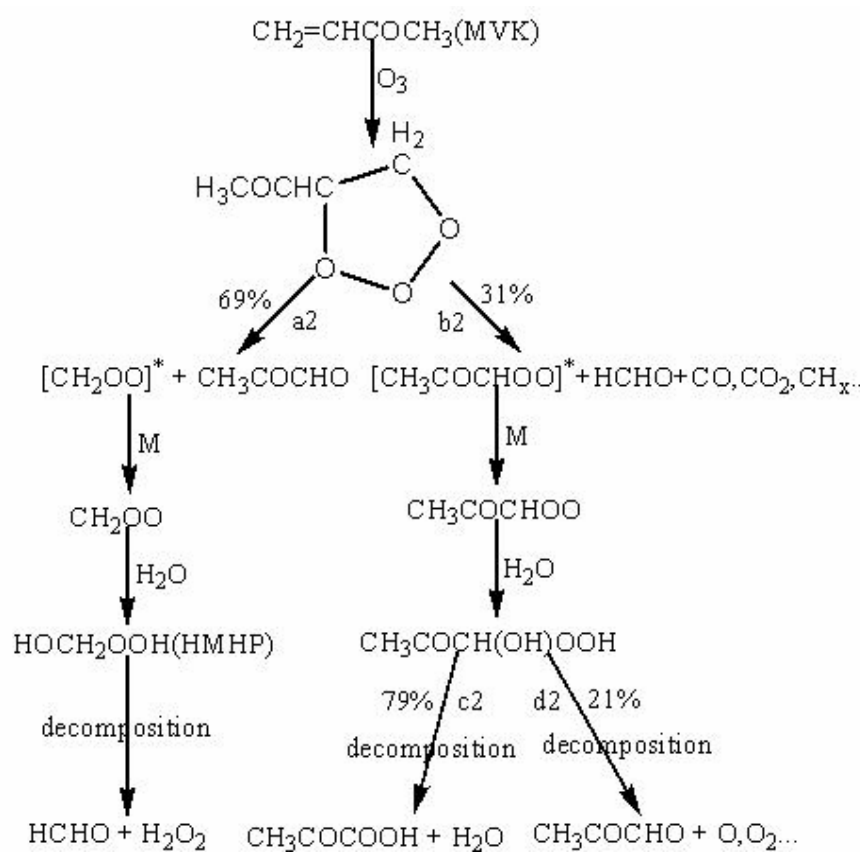

Fig. 5. Mechanisms of the ozonolysis of MAC and MVK in the aqueous phase.

unstable and decomposes rapidly into $\mathrm{H}_{2} \mathrm{O}_{2}$ and $\mathrm{HCHO}$ under a condition of $\mathrm{pH}>3$. $\quad\left[\mathrm{CH}_{3} \mathrm{C}(\mathrm{OO}) \mathrm{CHO}\right]^{*}$ formed in the $\mathrm{MAC}-\mathrm{O}_{3}$ reaction system reacts with $\mathrm{H}_{2} \mathrm{O}$ after stabilization to form $\mathrm{CH}_{3}(\mathrm{HOO}) \mathrm{C}(\mathrm{OH}) \mathrm{CHO}$, which is much more unstable than is HMHP and decomposes rapidly into MG. However, $\mathrm{H}_{2} \mathrm{O}_{2}$ cannot form during the decomposition of $\mathrm{CH}_{3}(\mathrm{HOO}) \mathrm{C}(\mathrm{OH}) \mathrm{CHO}$ because, unlike in HMHP, it is difficult for its $\alpha-\mathrm{OH}$ to react with the $-\mathrm{OOH}$ group because of a bigger steric effect caused by the carbonyl group in this molecule. Further study is needed to support this assumption. $\mathrm{CH}_{3}(\mathrm{HOO}) \mathrm{C}(\mathrm{OH}) \mathrm{CHO}$ was not detected in the experiment owing to its poor stability in the aqueous phase (Neeb et al., 1997; Sauer et al., 1999). The case is similar to the $\left[\mathrm{CH}_{3} \mathrm{COCHOO}\right]^{*}$ formed in the $\mathrm{MVK}-$ $\mathrm{O}_{3}$ reaction system, which is followed by the formation of $\mathrm{CH}_{3} \mathrm{COCH}(\mathrm{OH}) \mathrm{OOH}$. Unlike $\mathrm{CH}_{3}(\mathrm{HOO}) \mathrm{C}(\mathrm{OH}) \mathrm{CHO}$, there is a hydrogen atom on the carbon atom that bonds with the $-\mathrm{OOH}$ group in $\mathrm{CH}_{3} \mathrm{COCH}(\mathrm{OH}) \mathrm{OOH}$, and thus the decomposition of $\mathrm{CH}_{3} \mathrm{COCH}(\mathrm{OH}) \mathrm{OOH}$ has two pathways, forming PYA and MG (Sauer et al., 1999; Aplincourt and Anglada, 2003). $\mathrm{CH}_{3} \mathrm{COCH}(\mathrm{OH}) \mathrm{OOH}$ was not detected in the experiment because of its poor stability. However, there is also a hydrogen atom on the carbon atom that bonds with the $-\mathrm{OOH}$ group in HMHP but no acid is formed, which seems to be inconsistent with the formation of PYA from $\mathrm{CH}_{3} \mathrm{COCH}(\mathrm{OH}) \mathrm{OOH}$. Crehuet et al. (2001) confirmed that the water-assisted HMHP decomposition produced a lower activation barrier for the formation of $\mathrm{HCHO}+\mathrm{H}_{2} \mathrm{O}_{2}$ than that in the formation of $\mathrm{HCOOH}+\mathrm{H}_{2} \mathrm{O}$. This is consistent with the results of our study. In fact, Neeb et al. (1997) concluded that HMHP decomposed to yield $\mathrm{HCOOH}+\mathrm{H}_{2} \mathrm{O}$ almost exclusively, in agreement with the unimolecular process reported by Crehuet et al. (2001).

According to our experimental results, the formation of $\left[\mathrm{CH}_{2} \mathrm{OO}\right]^{*}$ dominated both of the aqueous $\mathrm{MAC}-\mathrm{O}_{3}$ and $\mathrm{MVK}-\mathrm{O}_{3}$ systems (Fig. 5). In the $\mathrm{MVK}-\mathrm{O}_{3}$ reaction system, the value of $\mathrm{b} 2$ was larger than the yield of $\mathrm{HCHO}$, possibly because some other compounds were formed from the decomposition of molozonide. In summary, because of the existence of huge amounts of water molecules, the Criegee radicals formed from the decomposition of ozonides in the aqueous ozonolysis of MAC and MVK were inclined to stabilize and then form peroxides and corresponding carbonyl compounds, rather than directly decompose into other products. Consequently, high yields of both peroxides and secondgeneration carbonyls were produced in both the $\mathrm{MAC}-\mathrm{O}_{3}$ and $\mathrm{MVK}-\mathrm{O}_{3}$ aqueous-phase reaction systems. The chemical stoichiometry of the aqueous ozonolysis of MAC and MVK can be presented as Reactions (1-3):

$$
\begin{aligned}
& \mathrm{MAC}+\mathrm{O}_{3} \rightarrow 0.99 \mathrm{MG}+0.70 \mathrm{HMHP}+0.32 \mathrm{HCHO} \\
& \mathrm{MVK}+\mathrm{O}_{3} \rightarrow 0.75 \mathrm{MG}+0.24 \mathrm{PYA}+0.69 \mathrm{HMHP} \\
&+0.13 \mathrm{HCHO}+0.18 \mathrm{C}_{1} \text { unknown } \\
& \mathrm{HMHP} \rightarrow \mathrm{HCHO}+\mathrm{H}_{2} \mathrm{O}_{2}
\end{aligned}
$$

In summary, when one molecule of ozone is consumed in the aqueous-phase ozonolysis of MAC and MVK, 0.7 molecules of peroxide and 1.6-2.0 molecules of carbonyl compound are produced. Therefore, in these processes, the type of oxidant is changed and the amount of oxidant is amplified. 


\section{Atmospheric implications}

The aqueous-phase reaction includes not only the reaction in the bulk of droplets but also the reaction on the surface of droplets. Moreover, nanometer-size water clusters, $\left(\mathrm{H}_{2} \mathrm{O}\right)_{n}$, which are ubiquitous in the atmosphere, are considered to potentially participate in the atmospheric chemistry (Ryzhkov et al., 2006; Sennikov et al., 2005). Therefore, generalized aqueous-phase ozonolysis of MAC and MVK in the atmosphere can be categorized into three chemical scenarios (Fig. 6): (i) in scenario 1 (the complete aqueous-phase reaction, i.e., bulk reaction), both $\mathrm{O}_{3}$ and MAC (or MVK) stay and react in the aqueous phase; (ii) in scenario $2 \mathrm{a}$ and scenario $2 b$ (the interfacial reaction), one reactant stays in the aqueous phase and reacts, via collision, with another reactant from the gas phase; and (iii) in scenario 3 (the interfacial reaction), neither $\mathrm{O}_{3}$ nor MAC (or MVK) stays in the aqueous phase but both can contact the aqueous phase simultaneously from the gas phase and react at the instant of contact. These scenarios may enlarge the aqueous-phase reaction scope than that considered usually in previous multiphase chemical models. Then, what is the percentage for each of the three reaction scenarios? This needs further laboratory and modeling studies. However, we strongly recommend the reaction on the surface of droplets including scenario 2 and scenario 3 is significant for a rapid reaction such as the ozonolysis of MAC and MVK. If so, the Henry constants mentioned previously would no longer be a key factor restricting the aqueous-phase reaction. Of course, this hypothesis should be further evaluated. In summary, the participation of the water molecules in the reaction is the key point for all three scenarios of the aqueous-phase reactions. Scenario 2 and scenario 3 cannot be carried out in laboratory simulations because, to our knowledge, it is difficult to distinguish between gas-phase and aqueous-phase reactions. Although only scenario 1 of aqueous reactions was performed in the present study, we suggest that the results can be extended to the whole aqueous-phase ozonolysis of MAC and MVK, including scenario 2 and scenario 3.

In the atmospheric aqueous phase, MAC and MVK may be oxidized potentially by $\mathrm{O}_{3}, \mathrm{OH}$ radicals, and $\mathrm{NO}_{3}$ radicals. On the basis of the rate constants and concentration levels of these oxidants, their relative importance in the oxidation of MAC and MVK can be compared with the lifetimes, as shown in Table 2.

From the lifetimes in the bulk of droplets estimated in Table 2, it seems that in the daytime, the $\mathrm{OH}$ radicals would dominate the oxidation of MAC and MVK, and in the nighttime when the $\mathrm{OH}$ concentration is very low, the $\mathrm{O}_{3}$ would dominate or compete with $\mathrm{NO}_{3}$ radicals. As can be seen from the abovementioned data, however, up to date, there are not enough studies for the aqueous-phase rate constants for the oxidation of MAC and MVK (Lilie and Henglein, 1970; Kumar et al., 1990; Pedersen and Sehested, 2001). Obviously, more studies for the accurate aqueous-phase rate constants
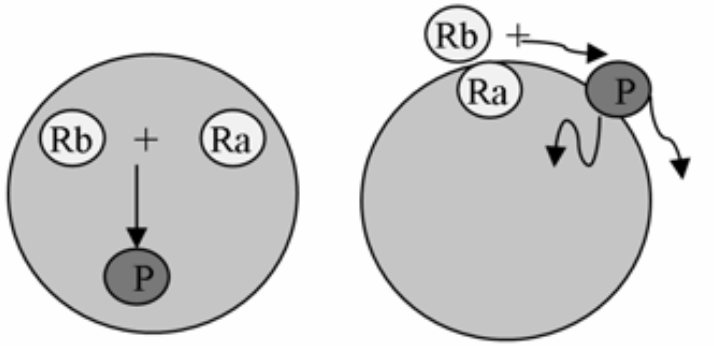

Scenario 1

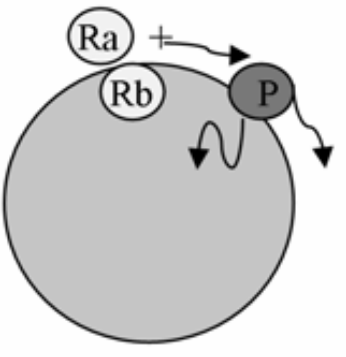

Scenario $2 b$

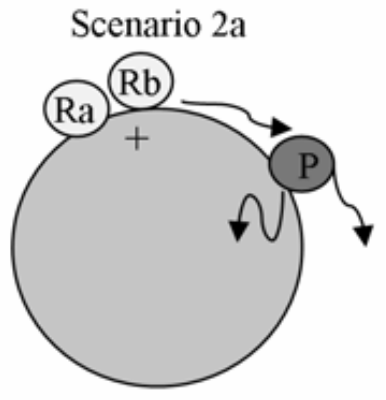

Scenario 3
Fig. 6. Different reaction scenarios for the aqueous-phase reaction. $\mathrm{Ra}$, reactant $\mathrm{a} ; \mathrm{Rb}$, reactant $\mathrm{b} ; \mathrm{P}$, product.

are needed to evaluate the relative importance of the three kinds of oxidants in the oxidation of MAC and MVK in the atmospheric aqueous phase.

The aqueous-phase reaction includes not only the reaction in the bulk of droplets but also the reaction on the surface of droplets, as shown in Fig. 6, and especially, the latter may be more important and more ubiquitous than the former in the atmosphere. The surface reaction rate depends upon the reaction rate constant and surface concentration of reactants. The surface concentration of reactants can be estimated according to the surface accommodation coefficients $\left(\alpha_{s}\right)$, when the desorption process could be negligible at the stage of initial adsorption or when the surface reaction rate is much larger than the desorption rate. $\alpha_{s}$ is defined as the probability that the molecules undergoes neither scattering nor immediate chemical reaction upon collision with the particle but is accommodated in the sorption layer of the particle $\left(0 \leq \alpha_{s} \leq 1\right)$ (Pöschl et al., 2007; Ammann and Pöschl, 2007). Based on the aqueous-phase reaction rate constants and the surface accommodation coefficients $\left(\alpha_{s}\right)$ of oxidants, the lifetimes of MAC and MVK reaction with oxidants on the surface of droplets may be estimated as following.

The uptake rate of the absorbate $\mathrm{OX}\left(r_{a}=\mathrm{d}\{\mathrm{OX}\} / \mathrm{dt}\right.$; here OX indicates an oxidant) by droplets can be given in Eq. (4):

$r_{a}=\frac{d\{O X\}}{d t}=\alpha_{s} Z$

$Z=\frac{1}{4} \bar{c} A_{s}[O X]$ 
Table 2. Comparison of atmospheric lifetimes of MAC and MVK reaction with different oxidants on the surface and in the bulk of droplets.

\begin{tabular}{|c|c|c|c|c|c|c|}
\hline & \multicolumn{3}{|c|}{ MAC } & \multicolumn{3}{|c|}{ MVK } \\
\hline & $\mathrm{O}_{3}$ & $\mathrm{OH}$ & $\mathrm{NO}_{3}$ & $\mathrm{O}_{3}$ & $\mathrm{OH}$ & $\mathrm{NO}_{3}$ \\
\hline$[\mathrm{OX}]_{g}\left(\mathrm{~cm}^{-3}\right)^{\mathrm{a}}$ & $7 \times 10^{11}$ & $1.6 \times 10^{6}$ & $5 \times 10^{8}$ & $7 \times 10^{11}$ & $1.6 \times 10^{6}$ & $5 \times 10^{8}$ \\
\hline $\begin{array}{l}\mathrm{H}\left(\mathrm{M} \mathrm{atm}^{-1}\right)^{\mathrm{b}} \\
298 \mathrm{~K}\end{array}$ & $1.14 \times 10^{-2}$ & 25 & 0.6 & $1.14 \times 10^{-2}$ & 25 & 0.6 \\
\hline$[\mathrm{OX}]_{a, e}(\mathrm{M})^{c}$ & $3.2 \times 10^{-11}$ & $1.6 \times 10^{-12}$ & $1.2 \times 10^{-11}$ & $3.2 \times 10^{-11}$ & $1.6 \times 10^{-12}$ & $1.2 \times 10^{-11}$ \\
\hline$\alpha_{s}^{\mathrm{d}}$ & 1 & 1 & 1 & 1 & 1 & 1 \\
\hline Molecularweight & 48 & 17 & 62 & 48 & 17 & 62 \\
\hline $\mathrm{k}\left(\mathrm{M}^{-1} \mathrm{~s}^{-1}\right)$ & $2.1 \times 10^{4 \mathrm{e}}$ & $5.8 \times 10^{9 \mathrm{f}}$ & $10^{3}-10^{6 \mathrm{~g}}$ & $4.4 \times 10^{4 \mathrm{e}}$ & $8.5 \times 10^{9 h}$ & $10^{3}-10^{6 \mathrm{~g}}$ \\
\hline$\tau_{\text {bulk }}(\mathrm{h})$ & 36 & 0.03 & $23-23000$ & 19 & 0.02 & $23-23000$ \\
\hline$\tau_{\text {surf ratio }}{ }^{\mathrm{i}}$ & 1 & 1.1 & $38-38000$ & 1 & 1.4 & $70-70000$ \\
\hline
\end{tabular}

${ }^{\mathrm{a}}$ where $\left[\mathrm{O}_{3}\right]_{g}$, the $24 \mathrm{~h}$ daytime and nighttime average concentration of $\mathrm{O}_{3}$ in the troposphere; $[\mathrm{OH}]_{g}$, the $12 \mathrm{~h}$ daytime average concentration of $\mathrm{OH}$ radicals in the troposphere; $\left[\mathrm{NO}_{3}\right]_{g}$, the $12 \mathrm{~h}$ nighttime average concentration of $\left[\mathrm{NO}_{3}\right]$ radicals in the troposphere.

$\mathrm{b}$ Ervens et al. (2003);

c $[\mathrm{OX}]_{a, e}$ aqueous-phase concentrations of oxidants at the gas-aqueous equilibrium;

d Although bulk accommodation coefficients $\left(\alpha_{b}\right)$ are available (Ervens et al., 2003), 0.05 for $\mathrm{OH}, 0.05$ for $\mathrm{O}_{3}$ and 0.004 for $\mathrm{NO}_{3}$, there are no measurements of surface accommodation coefficients $\left(\alpha_{s}\right)$ for these oxidants, they are likely to be very close to 1 (M. Ammann, private communication, 2008);

e Pedersen and Sehested (2001);

${ }^{\mathrm{f}}$ In analogy with $\mathrm{CH}_{3} \mathrm{CH}=\mathrm{CHCHO}$, (Lilie and Henglein, 1970);

$\mathrm{g}$ estimated from other organic compounds, Herrmann et al. (2005);

h Lilie and Henglein (1970);

${ }^{\mathrm{i}} \tau_{\text {surf }}$ ratio is estimated by the surface concentrations of oxidants and their aqueous-phase reaction rate constants with MAC and MVK. The surface concentration estimates from adsorption flux determined by $\alpha_{s}$, without considering desorption.

$\bar{c}=\sqrt{\frac{8 R T}{\pi M_{O X}}}$

where $Z$ is the rate of collisions between the gaseous molecules and droplet surface, $\alpha_{s}$ is the surface accommodation coefficient of oxidant, $\bar{c}$ is the mean molecular velocity of the gas molecules, $A_{s}$ is the effective surface area of droplets, $R$ is the gas constant, $T$ is the temperature and $M_{O X}$ is the molecular weight of the oxidant. $\{\mathrm{OX}\}$ indicates the concentration of oxidant on the surface of droplets, whereas $[\mathrm{OX}]$ indicates the gas-phase concentration of oxidant.

We can obtain:

$r_{a}=\frac{d\{O X\}}{d t} \propto \alpha_{s} \frac{[O X]}{\sqrt{M_{O X}}}$

at the beginning the surface concentration of oxidant were zero, then the concentration at time $t$ is

$\{O X\} \propto \frac{[O X]}{\sqrt{M_{O X}}} t$

By combining the aqueous-phase rate constants in Table 2 with Eq. (8), the ratio of the lifetimes of MAC and MVK reaction with different oxidants on the surface of droplets can be estimated as:

$$
\begin{aligned}
& \tau_{\mathrm{MAC}-\mathrm{O} 3}: \tau_{\mathrm{MAC}-\mathrm{OH}}: \tau_{\mathrm{MAC}-\mathrm{NO} 3}= \\
& \frac{1}{\left\{\mathrm{O}_{3}\right\} k_{\mathrm{MAC}-\mathrm{O} 3}}: \frac{1}{\{\mathrm{OH}\} k_{\mathrm{MAC}-\mathrm{OH}}}: \frac{1}{\left\{\mathrm{NO}_{3}\right\} k_{\mathrm{MAC}-\mathrm{NO} 3}} \\
& \tau_{\mathrm{MVK}-\mathrm{O} 3}: \tau_{\mathrm{MVK}-\mathrm{OH}}: \tau_{\mathrm{MVK}-\mathrm{NO} 3}= \\
& \frac{1}{\left\{\mathrm{O}_{3}\right\} k_{\mathrm{MVK}-\mathrm{O} 3}}: \frac{1}{\{\mathrm{OH}\} k_{\mathrm{MVK}-\mathrm{OH}}}: \frac{1}{\left\{\mathrm{NO}_{3}\right\} k_{\mathrm{MVK}-\mathrm{NO} 3}}
\end{aligned}
$$

Noticeably, in the description above, the desorption process on the surface of droplets is not considered. In fact, the surface concentration of a species should be obtained by combining the rates of adsorption and desorption. Obviously, the surface concentration without considering desorption should be higher than that with considering desorption. However, in the presence of a rapid surface reaction, such as the ozonolysis of MAC and MVK, the actual residence time of a reactant on the surface is much shorter than its desorption lifetime. In this case, the surface concentration of reactant may be limited to a low level, but its amount participating in the surface reaction may be considerable. Thus, it is difficult to estimate the accurate surface concentration of reactant, resulting 
in the difficulty in estimating the accurate lifetime of reactant. Additionally, up to date, there are no measured values of surface accommodation coefficients $\left(\alpha_{s}\right)$, although bulk accommodation coefficients $\left(\alpha_{b}\right)$ are available (Ervens et al., 2003). $\alpha_{s}$ is the maximum value for $\alpha_{b}$ (Pöschl et al., 2007), and the values of $\alpha_{s}$ are likely to be very close to 1 for many atmospheric relevant conditions (M. Ammann, private communication, 2008). In order to obtain the relative lifetimes of MAC and MVK oxidation on the surface of droplets, we choose the values of $\alpha_{s}$ as 1 for $\mathrm{OH}, \mathrm{O}_{3}$, and $\mathrm{NO}_{3}$, as shown in Table 2. The lifetime ratio results are shown in Table 2. We think the ratio of the lifetimes of MAC and MVK reaction with different oxidants on the surface of droplets may not be influenced greatly, especially for the case in the presence of rapid surface reaction, even though the desorption process is considered. Of course, this needs further study.

From Table 2, it can be seen, unlike the case in the bulk, that the $\mathrm{O}_{3}$ oxidation is comparable with the $\mathrm{OH}$ oxidation for MAC and MVK on the surface of droplets, whereas the $\mathrm{NO}_{3}$ oxidation is negligible. Obviously, this conclusion should be further evaluated using the more accurate parameters such as mass accommodation coefficients and aqueousphase rate constants. Although there is a great uncertainty, we suggest that the $\mathrm{O}_{3}$ oxidation of MAC and MVK is significant in the atmospheric aqueous phase.

Under simulated atmospheric conditions, including different temperatures and $\mathrm{pHs}$, the present laboratory study revealed that the ozonolysis of MAC and MVK in the aqueous phase can produce unexpectedly high yields of HMHP, MG and $\mathrm{HCHO}$, and $\mathrm{HMHP}$ can transform rapidly into $\mathrm{H}_{2} \mathrm{O}_{2}$ and $\mathrm{HCHO}$ with a yield of $100 \%$ because of its instability. In particular, these newly produced compounds are much more soluble than their precursors and are strongly inclined to stay in the aqueous phase $\left(\mathrm{H}_{\mathrm{HMHP}}=5.0 \times 10^{5} \mathrm{M} \mathrm{atm}^{-1}\right.$, $\mathrm{H}_{\mathrm{H} 2 \mathrm{O} 2}=1.0 \times 10^{5} \mathrm{M} \mathrm{atm}^{-1}$ at $295 \mathrm{~K} ; \mathrm{H}_{\mathrm{MG}}=3.7 \times 10^{4} \mathrm{M} \mathrm{atm}^{-1}$ at $295 \mathrm{~K} ; \mathrm{H}_{\mathrm{HCHO}}=6.3 \times 10^{3} \mathrm{M} \mathrm{atm}^{-1}$ at $298 \mathrm{~K}$ ) (Pandis and Seinfeld, 1989; Zhou and Lee, 1992; Lee and Zhou, 1993). However, the significance of a reaction in the atmosphere depends not only on the yield of its products but also on its reaction rate. The ozonolysis rate constants of MAC and MVK in the aqueous phase are extremely high (2.4 $( \pm 0.1) \times 10^{4} \mathrm{M}^{-1} \mathrm{~s}^{-1}$ and $4.4( \pm 0.2) \times 10^{4} \mathrm{M}^{-1} \mathrm{~s}$, respectively, Pederson and Sehested, 2001), so the rate bottleneck for these reactions is the amount of these two species participating in aqueous-phase reactions.

To the best of our knowledge, there have been no reports regarding the amount of MAC and MVK participating in aqueous-phase reactions, although it can be roughly estimated. According to recent studies, the yield of SOA from isoprene is about $1-3 \%$ under different atmospheric conditions, including the gas-phase reaction and aqueous-phase reaction (Henze et al., 2006; Hoyle et al., 2007; Matsunaga et al., 2005; Kroll et al., 2005, 2006). In accordance with the estimation of Böge et al. (2006) and Lim et al. (2006), the yield of SOA from aqueous-phase reaction is about $0.22 \%$.
Obviously, this yield should be controlled by two factors: (i) the amount of isoprene and its gas-phase oxidation products participating in aqueous-phase reactions; and (ii) the yield of SOA produced by the aqueous-phase oxidation of isoprene and its gas-phase oxidation products.

Like the aqueous-phase oxidation of sulfite [S(IV)] (Seinfeld and Pandis, 1998), and compared with oxidation by $\mathrm{H}_{2} \mathrm{O}_{2}$, oxidation by $\mathrm{O}_{3}$ might be the predominant pathway for the aqueous-phase oxidation of isoprene and its gas-phase oxidation products under a weak acidic condition (i.e. $\mathrm{pH} \geq 5$ ). Moreover, this $\mathrm{pH}$ condition is typical in the atmospheric aqueous-phase over the tropical rain forest zone where there is abundant vegetation and little anthropogenic activity. Consequently, in this region, oxidation by $\mathrm{H}_{2} \mathrm{O}_{2}$ could be a minor reaction pathway for isoprene and its gasphase oxidation products, and thus the yield of SOA might be low in atmospheric aqueous-phase reactions. Hence, it can be estimated that a considerable amount of isoprene and its gas-phase oxidation products reacts with oxidants on the surface or in the bulk of the aqueous phase. This is similar to the situation with MAC and MVK. Therefore, it is reasonable to conclude that a considerable amount of MAC and MVK can participate in aqueous-phase reactions in the atmosphere.

According to this analysis, the aqueous-phase ozonolysis of MAC and MVK produces a huge amount of peroxide and, thus, provides a direct source of oxidants to the atmospheric aqueous phase. Moreover, these reactions can also contribute a huge amount of MG and HCHO. These two carbonyl compounds might contribute a considerable amount of $\mathrm{HOx}(\mathrm{OH}$ and $\mathrm{HO}_{2}$ ) radicals and $\mathrm{H}_{2} \mathrm{O}_{2}$ by photolysis (Atkinson and Arey, 2003). Furthermore, HCHO can complex with S(IV) in the aqueous phase to produce hydroxymethanesulfonate (Seinfeld and Pandis, 1998), resulting in the reduction of peroxide consumption by S(IV). Therefore, the formation of MG and $\mathrm{HCHO}$ in the aqueous phase can be regarded as an indirect source of aqueous oxidants.

In conclusion, the aqueous-phase ozonolysis of MAC and MVK might be an important source of atmospheric aqueous oxidants. These aqueous oxidants, especially the peroxides, produced by the aqueous-phase reaction itself effectively confirm the formation of SOA from MAC via the mechanisms proposed by Claeys et al. (2004b), even if there are no other sources of aqueous oxidants. Moreover, the present study also provides supporting laboratory evidence for the field measurement. In this respect, Valverde-Canossa et al. (2005) suggested that organic peroxides, which were observed only in cloud samples, contributed to the total peroxides, from $14 \%$ during daytime to $80 \%$ during nighttime, and that the cloud ozonolysis reaction of alkenes was the main source of $\mathrm{H}_{2} \mathrm{O}_{2}$ during nighttime and of hydroxyalkyl hydroperoxides throughout the day. Therefore, the oxidants from aqueous-phase reactions might have a major role in aqueous-phase chemistry, especially in the formation of secondary aerosols (SAs), including sulfates and SOA, via aqueous-phase reactions. 
Further detailed laboratory and field experiments must be performed to determine the kinetic, phase-partitioning and other properties of the aqueous-phase reactions that would enable both a better understanding of the source of aqueous oxidants and judgment of the overall significance of aqueousphase chemistry in the formation of SAs.

Acknowledgements. The authors gratefully thank the National Natural Science Foundation of China (grants 20677002 and 20107001), and the Project of Development Plan of the State Key Fundamental Research of MOST of China (grant 2002CB410802), for their financial support.

Edited by: M. Ammann

\section{References}

Allen, J. M., Balcavage, W. X., Ramachandran, B. R., and Shrout, A. L.: Determination of Henry's law constants by equilibrium partitioning in a closed system using a new in situ optical absorbance method, Environ. Toxicol. Chem., 17, 1216-1221, 1998.

Ammann, M. and Pöschl, U.: Kinetic model framework for aerosol and cloud surface chemistry and gas-particle interactionsCPart2: exemplary practical applications and numerical simulations, Atmos. Chem. Phys., 7, 6025-6045, 2007,

http://www.atmos-chem-phys.net/7/6025/2007/.

Andreae, M. O. and Crutzen, P. J.: Atmospheric aerosols: biogeochemical sources and role in atmospheric chemistry, Science, 276, 1052-1058, 1997.

Anastasio, C., Faust, B. C., and Allen, J. M.: Aqueous phase photochemical formation of hydrogen peroxide in authentic cloud waters, J. Geophys. Res., 99, 8231-8248, 1994.

Aplincourt, P. and Angada, J. M.: Theoretical studies of the isoprene ozonolysis under troposheric condtions, 2. Unimolecular and water-assisted decomposition of the $\alpha$-hydroxyl hydroperoxides, J. Phys. Chem. A, 107, 5798-5811, 2003.

Atkinson, R. and Arey, J.: Atmospheric degradation of volatile organic compounds, Chem. Rev., 103, 4605-4683, 2003.

Biesenthal, T. A. and Shepson, P. B.: Observations of anthropogenic inputs of the isoprene oxidation products methyl vinyl ketone and methacrolein to the atmosphere, Geophys. Res. Lett., 24, 13751378, 1997.

Böge, O., Miao, Y., Plewka, A., and Herrmann, H.: Formation of secondary organic particulate phase compounds from isoprene gas-phase oxidation products: an aerosol chamber and field study, Atmos. Environ., 40, 2501-2509, 2006.

Chameides, W. L. and Davies, D. D.: The free radical chemistry of cloud droplets and its impact upon the composition of rain, J. Geophys. Res., 87, 4863-4877, 1982.

Claeys, M., Graham, B., Vas, G., Wang, W., Vermeylen, R., Pashynska, V., Cafmeyer, J., Guyon, P., Andreae, M. O., Artaxo, P., and Maenhaut, W.: Formation of secondary organic aerosols through photooxidation of isoprene, Science, 303, 1173-1176, 2004a.

Claeys, M., Wang, W., Ion, A. C., Kourtchev, I., Gelencsér, A., and Maenhaut, W.: Formation of secondary organic aerosols from isoprene and its gas-phase oxidation products through reaction with hydrogen peroxide, Atmos. Environ., 38, 4093-4098, 2004b.
Crehuet, R., Anglada, J. M., and Bofill, J. M.: Tropospheric formation of hydroxymethyl hydroperoxide, formic acid, $\mathrm{H}_{2} \mathrm{O}_{2}$, and $\mathrm{OH}$ from carbonyl oxide in the presence of water vapor: a theoretical study of the reaction mechanism, Chem. Eur. J., 7, 22272235, 2001.

Ervens, B., George, C., Williams, J. E., Buxton, G. V., Salmon, G. A., Bydder, M., Wilkinson, F., Dentener, F., Mirabel, P., and Herrmann, H.: CAPRAM 2.4 (MODAC mechanism): An extended and condensed tropospheric aqueous phase mechanism and its application, J. Geophys. Res., 108 (D14), doi:10.1029/2002JD002202, 2003.

Ervens, B., Carlton, A. G., Turpin, B. J., Altieri, K. E., Kreidenweis, S. M., and Feingold, G.: Secondary organic aerosol yields from cloud-processing of isoprene oxidation products, Geophys. Res. Lett., 35(2), L02816, doi:10.1029/2007GL031828,, 2008.

Finlayson-Pitts, B. J. and Pitts, J. N.: Chemistry of the Upper and Lower Atmosphere, Academic Press, New York, 2000.

Gäb, S., Hellpointner, E., Turner, W. V., and Korte, F.: Hydroxymethyl hydreoperoxide and bis(hydroxymethyl) peroxide from gas-phase ozonolysis of naturally occurring alkenes, Nature, 316, 535-536, 1985.

Gäb, S., Turner, W. V., and Wolff, S.: Formation of alkyl and hydroxyalkyl hydroperoxides on ozonolysis in water and in air, Atmos. Environ., 29, 2401-2407, 1995.

Gelencsér, A. and Varga, Z.: Evaluation of the atmospheric significance of multiphase reactions in atmospheric secondary organic aerosol formation, Atmos. Chem. Phys., 5, 2823-2831, 2005, http://www.atmos-chem-phys.net/5/2823/2005/.

Gierczak, T., Burkholder, J. B., Talukdar, R. K., Mellouki, A., Barone, S. B., and Ravishankara, A. R.: Atmospheric fate of methyl vinyl ketone and methacrolein, J. Photoch. Photobio. A, 110, 1-10, 1997.

Griffin, R., Cocker, D., Flagan, R., and Seinfeld, J.: Organic aerosol formation from the oxidation of biogenic hydrocarbons, J. Geophys. Res., 104, 3555-3567, 1999.

Guenther, A., Karl, T., Harley, P., Wiedinmyer, C., Palmer, P. I., and Geron, C.: Estimates of global terrestrial isoprene emissions using MEGAN (Model of Emissions of Gases and Aerosols from Nature), Atmos. Chem. Phys., 6, 3181-3210, 2006, http://www.atmos-chem-phys.net/6/3181/2006/.

Hatakeyama, S. and Akimoto, H.: Reactions of Criegee intermediates in the gas phase, Res. Chem. Intermediat., 20, 503-524, 1994.

Heikes, B. G.: Aqueous $\mathrm{H}_{2} \mathrm{O}_{2}$ production from $\mathrm{O}_{3}$ in glass impingers, Atmos. Environ., 18, 1433-1445, 1984.

Henze, D.K., and Seinfeld, J.H.: Global secondary organic aerosol from isoprene oxidation, Geophys. Res. Lett., 33, 1-4, 2006.

Herrmann, H., Tilgner, A., Barzaghi, P., Majdik, Z., Gligorovski, S., Poulain, L., and Monod, A.: Towards a more detailed description of tropospheric aqueous phase organic chemistry: CAPRAM 3.0., Atmo. Environ., 39, 4351-4363, 2005.

Hoyle, C. R., Berntsen, T., Myhre, G., and Isaksen, I. S. A.: Secondary organic aerosol in the global aerosol-chemical transport model Oslo CTM2, Atmos. Chem. Phys., 7, 5675-5694, 2007, http://www.atmos-chem-phys.net/7/5675/2007/.

Iraci, L. T., Baker, B. M., Tyndall, G. S., and Orlando, J. J.: Measurements of the Henry's law coefficients of 2-methyl-3-buten2-ol, methyacrolein, and methyl vinyl ketone, J. Atmos. Chem., 33, 321-330, 1999. 
Kavouras, I. G., Mihalopoulos, N., and Stephanou, E. G.: Formation of atmospheric particles from organic acids produced by forests, Nature, 395, 683-686, 1998.

Kavouras, I. G. and Stephanou, E. G.: Direct evidence of atmospheric secondary organic aerosol formation in forest atmosphere through heteromolecular nucleation, Environ. Sci. Technol., 36, 5083-5091, 2002.

Kroll, J. H., Ng, N. L., Murphy, S. M., Flagan, R. C., and Seinfeld, J. H.: Secondary organic aerosol formation from isoprene photooxidation, Environ. Sci. Technol., 40, 1869-1877, 2006.

Kroll, J. H., Ng, N. L., Murphy, S. M., Flagan, R. C., and Seinfeld, J. H.: Secondary organic aerosol formation from isoprene photooxidation under high- $\mathrm{NO}_{\mathrm{x}}$ conditions, Geophys. Res. Lett., 32, L18808, doi:10.1029/2005GL023637, 2005.

Kumar, M., Rao, M. H., and Moorthy, P. N.: Free-radical species from methyl vinyl ketone in aqueous-solution, a pulse-radiolysis study, J. Macromol. Sci. Chem., A27, 299-308, 1990.

Lee, Y. N. and Zhou, X.: Method for the determination of some soluble atmospheric carbonyl compounds, Environ. Sci. Technol., 27, 749-756, 1993.

Li, S., Chen, Z. M., Shao, K. S., and Tang, X. Y.: Study of atmospheric reaction between isoprene and $\mathrm{O}_{3}$, Chinese J. Environ. Sci., 18, 10-15, 1997.

Lilie, J. and Henglein, A.: Pulse radiolytic investigations on the oxidation of unsaturated carbonyl compounds in aqueous solution: hydrated enol as intermediate product, Ber. Bunsenges. Phys. Chem., 74, 388-393, 1970.

Lim, H. J., Carlton, A. G., and Turpin, B. J.: Isoprene forms secondary organic aerosol through cloud processing: model simulations, Environ. Sci. Technol., 39, 4441-4446, 2005.

Matsunaga, S., Wiedinmyer, C., Guenther, A. B., Orlando, J. J., Karl, T., Toohey, D. W., Greenberg, J. P., and Kajii, Y.: Isoprene oxidation products are a significant atmospheric aerosol component, Atmos. Chem. Phys. Discuss., 5, 11 143-11 156, 2005.

Montzka, S. A., Trainer, M., Goldan, P. D., Kuster, W. C., and Fehsenfeld, F. C.: Isoprene and its oxidation-products, methyl vinyl ketone and methacrolein, in the rural troposphere, J. Geophys. Res., 98, 1101-1111, 1993.

Novakov, T. and Penner, J. E.: Large contribution of organic aerosols to cloud-condensation-nuclei concentrations, Nature, 365, 823-826, 1993.

Neeb, P., Sauer, F., Horie, O., and Moortgat, G. K.: Formation of hydroxymethyl hydroperoxide and formic acid in alkene ozonolysis in the presence of water vapour, Atmos. Environ., 31, 14171423, 1997.

Pandis, S. N. and Seinfeld, J. H.: Sensitivity analysis of a chemical mechanism for aqueous-phase atmospheric chemistry, J. Geophys. Res., 94, 1105-1126, 1989.

Pedersen, T. and Sehested, K.: Rate constants and activation energies for ozonolysis of isoprene methacrolein and methyl-vinylketone in aqueous solution: significance to the in cloud ozonation of isoprene, Int. J. Chem. Kinet., 33, 182-190, 2001.

Penner, J. E., Andreae, M., Annegarn, H., Barrie, L., Feichter, J., Hegg, D., Jayaraman, A., Leaitch, R., Murphy, D., Nganga, J., and Pitari, G.: Climate Change 2001: the Scientific Basis. Contribution of Working Group I to the Third Assessment Report of the Intergovernmental Panel on Climate Change, Cambridge University Press, 289-348, 2001.
Pöschl, U., Rudich, Y., and Ammann, M.: Kinetic model framework for aerosol and cloud surface chemistry and gas-particle interactionsCPart 1: General equations, parameters, and terminology, Atmos. Chem. Phys., 7, 5989-6023, 2007, http://www.atmos-chem-phys.net/7/5989/2007/.

Pruppacher, H. R. and Klett, J. D.: Microphysics of Clouds and Precipitation, 2nd edn, Kluwer Academic Publishers, Dordrecht, The Netherlands, 23, 1997.

Quivet, E., Liu, Y., Haddad, E., Temime, B., Marchand, N., Monod, A., Michaud, V., Sellegri, K., and Laj, P.: Formation of secondary organic aerosols through in-cloud aqueous phase photooxidation of methacrolein, International Science Meeting of the ESF networks VOCBAS and INTROP "Biogenic Volatile Organic Compounds: Sources and fates in a changing world", Montpellier, France, 2-5 October 2007.

Ryzhkov, A. B. and Ariya, P.A.: The importance of water clusters $\left(\mathrm{H}_{2} \mathrm{O}\right)_{n}(\mathrm{n}=2, \ldots, 4)$ in the reaction of Criegee intermediate with water in the atmosphere, Chem. Phys. Lett., 419, 479-485, 2006.

Sauer, F., Christian, S., Neeb, P., Horie, O., and Moortgat, G. K.: Formation of hydrogen peroxide in the ozonolysis of isoprene and simple alkenes under humid conditions, Atmos. Environ., 33, 229-241, 1999.

Seinfeld, J. H. and Pandis, S. N.: Atmospheric Chemistry and Physics, John Wiley \& Sons, 1998.

Sennikov, P. G., Ignatov, S. K., and Schrems, O.: Complexes and clusters of water relevant to atmospheric chemistry: $\mathrm{H}_{2} \mathrm{O}$ complexes with oxidants, Chem. Phys. Chem, 6(3), 392-412, 2005.

Simpson, D., Winiwarter, W., Borjesson, G., Cinderby, S., Ferreiro, A., Guenther, A., Hewitt, C. N., Janson, R., Khalil, M. A. K., Owen, S., Pierce, T. E., Puxbaum, H., Shearer, M., Skiba, U., Steinbrecher, R., Tarrason, L., and Oquist, M. G.: Inventorying emissions from nature in Europe, J. Geophys. Res., 104, 81138152, 1999.

Surratt, J. D., Murphy, S. M., Kroll, J. H., Ng, N. L., Hildebrandt, L., Sorooshian, A., Szmigielski, R., Vermeylen, R., Maenhaut, W., Claeys, M., Flagan, R. C., and Seinfeld, J. H.: Chemical composition of secondary organic aerosol formed from the potooxidation of isoprene, J. Phys. Chem. A, 110, 9665-9690, 2006.

Tsigaridis, K. and Kanakidou, M.: Secondary organic aerosol importance in the future atmosphere, Atmos. Environ., 41, 46824692, 2007.

Valverde-Canossa, J., Wieprecht, W., Acker, K., and Moortgat, G. $\mathrm{K}$.: $\mathrm{H}_{2} \mathrm{O}_{2}$ and organic peroxide measurements in an orographic cloud: The FEBUKO experiment, Atmos. Environ., 39, 42794290, 2005.

Wiedinmyer, C., Tie, X., and Guenther, A.: Future changes in biogenic isoprene emissions: how might they affect regional and global atmospheric chemistry?, Earth Int., 10, 1-19, 2006.

Xu, J. R. and Chen, Z. M.: Determination of peroxides in environmental samples by high performance liquid chromatography with fluorescence detection, Chinese J. Chromatogr., 23, 366369, 2005.

Zhou, X. L. and Lee, Y. N.: Aqueous solubility and reaction kinetics of hydroxymethyl hydroperoxide, J. Phys. Chem., 96, 265-272, 1992.

Zabernick, S. and Heicklen, J.: Reactions of alkoxy radicals with $\mathrm{O}_{2}$. I. $\mathrm{C}_{2} \mathrm{H}_{5} \mathrm{O}$ radicals, Int. J. Chem. Kinet., 17, 455-476, 1985. 